\title{
The Basis and Structure of Attitudes: A Critical Evaluation of Experimental, Discursive, and Social Constructionist Psychological Perspectives
}

\author{
Tim Dlamini*, Dominic Willmott and Saskia Ryan \\ Department of Psychology, University of Huddersfield, UK
}

Submission: March 09, 2017; Published: August 29, 2017

*Corresponding author: Tim Dlamini, Doctoral Researcher in Psychology, University of Huddersfield, Huddersfield, HD1 3DH; Email: Themba.Dlamini@hud.ac.uk

\begin{abstract}
This piece will examine the concept of attitudes from three alternative perspectives, exploring which has greater utility for the interpretation and assessment of such governing constructs. Experimental psychologists study attitudes cognitively, arguing for the existence of such an entity. Discursive psychologists argue against the study of 'attitudes,' proposing instead those attitudes should be considered as social constructions which occur through language. Notably, social constructionists claim that categories and concepts that people use to understand psychological phenomena and the world around them are historically, culturally, and contextually specific. The many differing viewpoints and explanations put forward from these perspectives are considered here along with assessing how reliable theory and research conducted to date is deemed to be.

Keywords: Attitudes; Social Cognition; Social Constructions; Discursive Psychology
\end{abstract}

\section{Introduction}

The definition of an attitude has remained free from complete consensus and there are, as has remained the case over time, many different definitions. One early yet basic definition by Edwards [1] suggests an attitude to be the degree of positive or negative affect held for a psychological object. A more detailed operationalized definition still widely accepted today is that of Zanna and Rempel [2] who suggest, "we regard an attitude as the categorisation of a stimulus object along an evaluative dimension based upon, or generated from, three general classes of information: (1) cognitive information, (2) affective/ emotional information, and/or (3) information concerning past behaviours or behavioural intentions".

\section{Experimental Approach}

Experimental psychology explores the concept of 'attitudes' from a cognitive perspective arguing that attitudes exist, are susceptible to change over time and influence behaviour, thus can be measured and studied Willmott et al. [3]. It is also thought that attitudes are affected by previous experience, which can have both positive and negative influence upon future behaviour Fishbein, Ajzen [4]. Within the cognitive study of attitudes, research has investigated, and sought to establish a relationship between attitude and behaviour and whether in fact, people act on the attitudes they hold towards a stimulus object. Much research has claimed to have found direct evidence of attitudes predicting behavioural outcomes within a forensic domain, including; jury voting decisions during trials Willmott [5], biased eyewitness suspect identifications Willmott [6]; Willmott and Sherretts [7], and the continuation of criminal behaviour Willmott and Sherretts [7].

The Theory of Reasoned Action was put forward by Fishbein and Ajzen [4], to test if voluntary behaviour precedes an attitude. The theory is that the weighing up of an attitude held towards something (evaluation of belief's about the behaviour) and subjective norm (assessment of other people's opinions of what the intention will be) lead to a behaviour being intended or not and subsequently performed Fishbein and Ajzen [4]. The theory proposes the best way to predict behaviour is to ask if the person intends to do it or not Fishbein and Ajzen [4].

Although the model has proven of use in the prediction of consumer behaviour intentions Sheppard et al. [8] and been used in numerous studies Hale et al. [9], the theory is subject to critique for being reductionist and not taking into account other variables within the attitude component of the theory. For example, the salience or relevance of a stimulus objects Bass 
and Rosen [10] which may also have an effect on behaviour. Also, the context in which an attitude is formed is suggested to effect predictability of behaviour with Fazio and Zanna [11] suggesting direct experience with the attitude object is likely to more accurately predict behaviour, than indirect, less confident experience which the theory does not account for. The model is also criticized by Aiken [12] for not providing an explanation for the findings of research that suggests past behaviour is often the best predictor of future behaviour and may therefore be lacking in comprehensiveness.

'Ajzen [13] developed the theory further into what was called the theory of planned behaviour which in addition to the type of attitude and subjective norms held, adds the concept of perceived behavioural control. Ajzen [13] stated this involved the individual perceiving the ease or difficulty of actually performing a particular behaviour, determined by factors seen to facilitate or impair the behaviour known as 'accessible control beliefs.' The theory is supported by several subsequent studies showing changes helped better predict behaviour intentions than the original theory a especially in health related areas such as exercise, healthy eating, and safe sex practices Ajzen [13]. Giles and Cairns [14] study also found the application of the theory's components could account for two-thirds of studied behaviours. However, this is in contrast to Wickers [15] similar study reviews of the theory's application which found only $10 \%$ support. As a general look at the attitude behaviour link Potter [16] criticises the utility of the attitude concept, which he suggests was made powerful by its claim that once an attitude had been quantitatively measured, subsequent behaviour could then be predicted yet some of the aforementioned research has shown this not to be the case La Piere [17]; Corey [18]; Wicker [19] and even when supported, not with full certainty. This leads to questioning the usefulness of attitude theory's overall Potter [16] and the suggestion that there is something else operating in the relationship between behaviour and attitude.

A classic study conducted by La Piere [17] whereby a Chinese couple were taken to over 200 establishments at a time of open racism in America, found they were only turned away once, but when asked sometime after if they were willing to accept Chinese people as guests, $92 \%$ of the same venues who replied, claimed they were not, and only one said yes. Providing a strong indication that there is an inconsistency between what people say and do. Subsequent research by Corey [18] and a metaanalysis by Wicker [19], concurred with this finding. Providing evidence for both variations of the theory and that behaviour does precede attitudes held.

Also discussed through a cognitive perspective of attitude study is Cognitive Dissonance Theory, defined as a distressing mental state whereby people find themselves holding contradictory ideas at the same time Festinger [19]. This subsequently motivates them to reduce dissonance through justifying and rationalising behaviour to themselves, leading to subsequent changes in attitudes Augoustinos and Walker [20]. Cognitive Dissonance is thought to be caused by this rationalisation causing conflict with the individuals' self-concept that can lead to confirmation bias Festinger [20]. This theory has been applied to a wealth of research and has offered support for the notion that attitudes precede behaviour (Aronson 1989; Opton 1971; Willmott, 2017a; Willmott \& Oostinga, 2017).

Alternatively, Bem [26] criticised the emphasis the theory placed on how much people think about contradictory attitudes, suggesting instead the Self-Perception Theory, whereby attitudes are inferred by looking at an individual's own behaviour. Discursive psychologists criticise this theory on the basis of it being entwined with consistency theories, arguing that assuming people are motivated to be consistent and balanced in attitudes and beliefs they hold is inaccurate, as people are far more tolerant of cognitive inconsistencies than the theory assumes Billig [27]. The concept was also challenged by Cooper and Fazio [28] who suggested dissonance was not caused by inconsistency of beliefs, but due to the negative consequences associated with something such as a lie.

\section{Discursive Approach}

The Discursive approach examines how arguments and opinions are constructed in society and culture, through the use of language potter and Wetherell [29]. Potter [27] states that through this perspective, an 'attitude' is not viewed as an abstract construct or entity that individuals possess, but a concept that people use to make sense of the world and proposed three basic elements of discourse that explain this. Construction ; whereby people construct versions of events from interactions differently and how these versions are subsequently established. Action; where actions and recourses are performed by people when talking and writing, revealed through analysing discourse such as defending the self, criticising or persuading others, and Rhetoric ; believed to be used to counter conflicting alternatives of events and action that individuals have an interest in Edwaards and Potter [30]. Potter used the discursive analysis of Chancellor Lawson's resignation from Margaret Thatcher's cabinet in 1989 to support this idea, finding elements of the three components in the chancellor's subsequent interview discourse, believed to be aimed to counter Thatcher's version of events in the parliament as mentioned above exchange Edwards, Potter [1].

Billig [31] also supports this idea, suggesting that people's versions of events are usually designed to counter alternatives in ongoing arguments, as do Wetherell and Maybin [32] who state as the discursive perspective is a Social Constructionist Theory, the interaction not the individual should be studied and therefore the chancellors resignation should be examined in terms of motives which may have arisen from interactions and social constructions, not motives in the abstract sense of inner psychological space.

The discourse of opinions and arguments expressed 
through everyday interaction's such as conversation are also studied by looking at peoples representations, evaluations, and resources that are drawn on to establish what functions they serve. Atkinson [33-35] proposed the idea of political oratory whereby talk is structured in a way to have persuasive influence. The three components are suggested to be the skilful use of language, which has observable measures of success such as audience's responses to speech, made effective from skills used in everyday conversation Heritage and Greatbatch [36]. Combined with several other features Atkinson suggested, such as naming individuals, three part lists and contrasting views can have persuasive manipulation effects Potter [16]. This concept is supported by Atkinson's own discursive analyses of political speeches Atkinson [37] and that of Jefferson [38] who found lists commonly consisted of three parts in conversation.

A classic study by Pomerantz [39] who analysed conversations in real life settings, found when a speaker made evaluative assessments, the recipient commonly put forward their own assessment straight after, such as an audience clapping a speech, which also strengthens Atkinson's concept However, Atkinson [30] himself, and Heritage, Greatbatch [36], do suggest that devices used by orators to gain applause are extensive and not fully known.

Heritage and Greatbatch [36] developed Atkinson's [30] concept studying political party speeches in 1981 Britain and identified six 'rhetorical formats' for oratory persuasion and found although two-thirds of 1588 sets of applause proceeded combinations of the six rhetoric formats, the other third set of applauses were unexplained under political oratory concepts Heritage and Greatbatch [36].

Many scholars have made strong suggestions about the importance of recognising the social, historical, and ideological origins of psychological concepts e.g. Gergen [40]; Sampson [41]; Parker [42]. In her recent writings, Burr [43] asserts that while there are theoretical differences within mainstream psychology, its adherence to what she calls an "essentialist model' (p.6) focuses on the unique and self-contained individual, as such attitudes, beliefs, thoughts, and memories are acknowledged as psychological structures that are intrinsically part and parcel of being human. Conversely, an argument put forward by social constructionist is, according to Burr 'that there are no essences inside people that make them what they are' (p.6). In this sense, social construction takes a different direction from the notion of essentialism upheld by mainstream psychology.

\section{Social Constructions}

For Gergen [44], construction challenges conventional knowledge and represents an orientation to social reality and understandings. In his depiction of social construction as a movement in modern psychology, Gergen [45] argues that what human beings take to be knowledge of the world is not a product of induction or the testing of hypothesis but rather constructed through language, culture and context. Gergen [45] further argues that many social psychologists, which are influenced by the constructionist claims, are dissatisfied with the political implications of human experimentation, and choose instead to explore how reality and psychological phenomena is constructed within the society.

While conventional psychology has predominantly theorized people attitudes from an individualist perspective or 'essentialist model' Burr [46], and consequently giving value to isolation over relationships, it is, therefore, compelling to look beyond an individual level. We are drawn towards claims made by social constructionists and discursive psychology and these are discussed here rather more generally. Many proponents of social construction and discursive psychologist have taken a stronger view towards understanding people's attitudes from a profoundly socialized notion of the self as an alternative to the individualistic, and predominantly reductionist approach favoured by mainstream social psychology (E.g. Burr [43]; Potter and Wetherell [39]; Gergen [47]; Shotter [48]; Sampson [41]; Hermans and Kempen [49].

The approach taken by experimental psychologists to studying people's attitudes and other psychological entities has not only allowed social constructionists to critique and question individualism as a way of understanding people's behaviour, despite having dominated psychology's history, but position social psychology more towards exploring patterns of relationship and language as a knowledge generating platform Gergen [50]. It further argues that in the postmodern era, the immediacy of human relationships dissolves the self, thus making it lose its traditional sense of logic and integrity.

On a similar viewpoint, Burr [43] asserts that people's identity originates not from inside the person, but from the social world. Burr further argues that even particular diseases are not objectively defined medical objects but are social entities. For example, Burr [43] takes us back to when homosexuality...'was a disease under the Diagnostic Statistical Manual of Mental Disorders (DSM-II), but after transformations in social attitudes and campaigns, it was removed from the list. From this, it is apparent that cultural contexts, norms, and beliefs can influence people's attitudes, and therefore shape their reality and understandings.

Burr [43] further raises an interesting comment that the role of language within social construction is not a straightforward vehicle for transmitting thoughts and feelings, but in fact makes thoughts possible by constructing concepts. Put simply, Burr suggests that it is language that makes thoughts and concepts possible. Since language provides a means of structuring the way the world is experienced and predates concepts, the social constructionist's claim that people's attitudes and all so-called realities of social life are constructed, negotiated and situated in particular historical circumstances is much less of an unsubstantiated claim but one which is compelling. 
As explained in the introduction, the cognitive stance argues that attitudes exist, change over time and influence behaviour, whereas Burr [43]writes that discursive psychology acknowledges mental processes but, similar to behaviourism, does not relate mental processes to understanding behaviour. Another concept closely aligned to the general views held by social constructionists is that conceptualised by symbolic interactions, which, as put by Flory [51], suggest 'society and individuals are the product of interaction between people and that this interaction takes place through the use of symbols which have to mean for the individuals involved'.

Returning briefly to the subject of language and attitudes, Kraus and Chiu [52] points out that language permeates social life and is the foremost pathway on which cultural knowledge is transmitted. Thus, language is a primary means by which individuals gain access to the contents of other peoples' mind Krauss and Chiu [52]. Interestingly, Bandura, in his social cognitive theory of personality, notes a 'reciprocal causality' thus internal personal factors [cognitive, affective and biological events], behavioural patterns and environmental events (social) all interact, bi-directionally, as determinants that influence one another. According to Bandura, human adaptation and change are rooted in social systems however, in suggesting the notion of reciprocal causality, Bandura overlooks the role of language as a means in which social systems operate. He further argues that 'personal agency operates within a broad network of sociostructural influences' and that people are producers as well as products of social systems Bandura [53].

However, Burr [46] suggests a need for a critical stance toward understanding the world and taken for granted aspects of knowledge. She further argues that while mainstream psychology's agenda lies around the discovery of psychological phenomena, such as how attitudes are moulded among people, social constructionism argues that the ways in which we commonly understand the world, the categories and concepts we use (e.g., attitudes) are historically and culturally specific (p.4).

Language and meanings embedded in it, has, in general, been of interest to discursive psychologists Billig [54] and social constructionists Burr [46]. According to Burr, people acquire concepts and categories through language and this is further sustained over time by those who share a particular culture and language. From a discursive psychological viewpoint Potter and Hepburn [55] argue that instead of seeing attitudes as mental entities that influence behaviour (as theorised in social cognition) and as already discussed above in the Theory of Planned Behaviour Ajzen [56], discursive psychologists conceptualise them in terms of discourse. 'For the purpose of understanding entities such as attitudes, perception and memory, to name few, Potter and Hepburn (2007, p.2) assert that it is not discursive psychology's aim 'to get inside people's heads to get at these entities' but rather, the focus is directed on 'talk and text in social practices'.

\section{Conclusion}

Overall, experimental psychologists offer much critique over discursive approaches, questioning how reliable generalisations and representation of the findings are from discourse when a causal effect is established without systematic experimental investigation Abram and Hogg [57]. However, Potter and Wetherell [48] proposed a counter critique by stating that by focusing on the organisation of discourse and what the speaker is aiming to do «discourse analysis does not take for granted accounts reflecting underlying attitudes and dispositions» as does cognitive attitude study. Potter [55] also claims that looking at evaluative expressions through discourse and conversation analysis in naturalistic studies, is more productive than looking at attitudes as discrete cognitive entities conducted in false experimental settings. Measurement scales used in cognitive attitude study such as Likert attitude scales, have been criticised from a discursive perspective as research carried out in New Zealand towards racism suggests people modify their evaluations and description on a momentary basis depending on the context they're in, and thus the measurement scales don't adequately measure 'attitudes' other than in that context, at that time Wetherell and Potter [55].

Alternatively, Azjen [50] states attitude is a hypothetical construct that is not directly observable but becomes observable and measurable using Likert scales to determine a degree of attitude which discursive psychology cannot do. Certainly, a wealth of research has made use of such scales within the domain of experimental psychology for prosocial assessment and change Willmott [59]. However the discursive perspective disagrees that attitudes can be measured at all, with Potter and Wetherell [55] criticising methods of measuring an 'attitude,' opposing that selfreported questionnaires have the power to assess participant's internal mental state at all. Both of the perspectives have been discussed and evaluated on their usefulness supported by both theory and research in the 'attitude' existence debate. As has been argued, the different points of view agree that meaning is constructed through language but, disagree with how it should be studied and what is actually constructed. What can be drawn from the research conducted for this piece is, although the cognitive experimental approach has firm roots in its work on attitudes over the years and has much supporting theory and literature, it also has a lot of criticism and refuting literature. The discursive approach to examining attitudes through the construction of language on worldly events seems to have much contemporary, supportive research and excitement generated around it.

The discursive theoretical methods discussed in this piece are but a tiny selection of concepts, theories, and methods of analysing language which seems to be ever growing and has 
much scope for useful developments in the future study of worldly events and psychological phenomena. Abram and Hogg [57] make a final useful concluding statement on the debate between the perspectives, stating would it not be better for discursive analysis be integrated with, rather than set against, social psychology, a question that time may answer [60-63].

\section{References}

1. Edwards AL (1957) Techniques of attitude scale construction Appleton-Century-Crofts, New York, USA.

2. Zanna MP, Rempel JK (1988) Attitudes: A new look at an old concept In: Bartal D, Kruglanski AK, (Eds.). The social psychology of knowledge. Cambridge University Press, Cambridge, USA.

3. Willmott D, Mojtahedi D, Ryan S, Sherretts N, Simpson O, et al. (2017) Psychometric tests as a measure of Personality: A Critical Assessment of Trait versus Situationalist Positions and the NEO Personality Inventory (NEO-PI-R). EC Psychology and Psychiatry 3(1): 13-18.

4. Fishbein M, Ajzen I (1975) Belief, attitude, intention, and behaviour: An Introduction to theory and research. Addison-Wesley, Massachusetts, USA.

5. Willmott D (2016a) Is Jury Bias Preventing Justice for Rape Victims? The Conversation.

6. Willmott D (2017b) Is it Strange or is it Scary? Examining Salience and Arousal Explanations of the "Weapons Focus Effect". Internet Journal of Criminology.

7. Willmott D, Sherretts N (2016) Individual Differences in Eyewitness Identification Accuracy between Sequential and Simultaneous Lineups: Consequences for Police Practice and Jury Decisions. Current Issues in Personality Psychology 4(4): 228-239.

8. Sheppard BH, Hartwick J, Warshaw PR (1988) The theory of reasoned action: A meta-analysis of past research with recommendations for modifications and future research. Journal of Consumer Research 15: 325-343.

9. Hale JL, Householder BJ, Greene KL (2003) The theory of reasoned action. In: JP Dillard, Pfau M, (Eds.). The persuasion handbook: Developments in theory and practice. California, USA.

10. Bass AR, Rosen H (1969) Some potential moderator variables in attitude research. Educational and Psychological Measurement 29(2): 331-348.

11. Fazio RH, Zanna MP (1978) Attitudinal qualities relating to the strength of the attitude-behaviour relationship. Journal of Experimental Social Psychology 14: 228-243.

12. Aiken LR (2002) Attitudes and related psychosocial constructs: Theories, Assessment and research. London.

13. Ajzen I (1988) Attitudes, Personality and Behaviour, Chicago, USA.

14. Giles M, Cairns E (1995) Blood donation and Azjen's theory of planned behaviour: An examination of perceived behavioural control. British Journal of Social Psychology 34(1): 178-188.

15. Wicker AW (1971) An examination of the "other variables" explanation of the attitude-behaviour inconsistency. Journal of personality and social psychology 19: 18-30.

16. Potter T (1996) Attitudes, Social Representations and Discursive psychology. In: Wetherell M, (Eds.) Social psychology: Identities, groups and social issues London.

17. La Piere R (1934) Attitudes vs. Actions. Social Forces 13: 230-237.

18. Corey SM (1937) Professed attitudes and actual behaviour. Journal of Educational Psychology, 28: 145-148.
19. Festinger L (1957) A theory of cognitive dissonance. Stanford University Press, California, USA.

20. Augoustinos M, Walker I (1995) Social Cognition: An integrated Introduction. London.

21. Festinger L, Riecken HW, Schachter S (1956) When prophecy fails. University of Minnesota Press, USA.

22. Aronson E (1989) Analysis, synthesis, and the treasuring of the old' Personality and Social. Psychology Bulletin 15(4): 508-512.

23. Opton EM (1971) It never happened and besides they deserved it. In: Sanford N, Comstock C (Eds.). Sanctions for evil, Jossey-Bass, San Francisco, USA.

24. Willmott D (2017a) Jury Psychology. In B Baker, R Minhas, L Wilson (Eds.). Psychology and Law: Factbook ( $2^{\text {nd }}$ edn.). European Association of Psychology and Law.

25. Willmott D, Oostinga M (2017) Scientific Jury Selection. In B Baker, R Minha, L Wilson (Eds.). Psychology and Law: Factbook (2 $2^{\text {nd }}$ edn.). European Association of Psychology and Law.

26. Bem DJ (1967) Self-perception: An alternative interpretation of cognitive dissonance phenomena. Psychological Review 74(3): 183200.

27. Billig M (1987) Arguing and thinking: A rhetorical approach to social psychology. University Press, Cambridge, USA.

28. Cooper J, Fazio RH (1984) A new look at dissonance theory. In: Berkowitz L (Eds.). Advances in experimental social psychology. Academic Press, New York, USA.

29. Potter J, Wetherell M (1987) Discourse and Social Psychology: Beyond Attitudes and Behaviour. London.

30. Edwards D, Potter J (1992) Discursive psychology.

31. Billig M (1992) Studying the thinking society: Social representations, rhetoric and attitudes. In: Breakwell G, Canter D (Eds.). Empirical approaches to social representations. Oxford University Press, UK.

32. Wetherell M, Maybin J (1996) The distributed self: A social Constructionist perspective. In: Stevens R (Eds.). Social Psychology: Understanding the self. London.

33. Atkinson JM (1983) Two devices for generating audience approval: A comparative analysis of public Discourse and texts. In: Ehlinch K, Van Riemsdijk H (Eds.). Connectedness in sentence, Discourse and text Tilburg: Tilburg Papers in Linguistics.

34. Atkinson JM (1984a) Our master's voices: The Language and body of politics. London. Methuen.

35. Atkinson JM (1984b) Public speaking and audience response: some techniques for inviting applause. In: Atkinson JM, Heritage JC (Eds.) Structures of social action: Studies in Conversation analysis Cambridge University Press, Cambridge, USA.

36. Heritage J, Greatbatch D (1986) Generating applause: A study of Rhetoric and response at political conferences. American Journal of Sociology 92: 110-157.

37. Atkinson JM (1985) Refusing invited applause: Preliminary observations from a case study of Charismatic Oratory. In: Van Dijk TA (Eds.). A Handbook of Discourse analysis. $3^{\text {rd }}$ edn. New York: Academic Press.

38. Jefferson G (1989) Preliminary notes on a possible metric which provides for a standard maximum' silence of approximately one second in conversation. Multilingual Matters.

39. Pomerantz A (1984) Agreeing and disagreeing with assessments: Some features of preferred/Dispreferred turn shapes. In: Atkinson JM, Heritage J (Eds.). Structures of social action: Studies in Conversation analysis Cambridge: University Press, Cambridge, USA. 
40. Gergen KJ (1973) Social psychology as history. Journal of personality and social psychology 26(2): 309.

41. Sampson EE (1988) The debate on individualism: Indigenous psychologies of the individual and their role in personal and societal functioning. American psychologist 43(1): 15.

42. Parker I (1990) Discourse: Definitions and contradictions. Philosophical psychology 3(3): 187-204.

43. Burr V (2015) Social construction. Routledge, London.

44. Gergen KJ (1985) The social constructionist movement in modern psychology. American psychologist 40(3): 266.

45. Gergen KJ (1996) Social psychology as social construction: The emerging vision. The message of social psychology: Perspectives on mind in society 113-128.

46. Burr V (1995) An introduction to social construction. Routlegde, London.

47. Gergen KJ, Gulerce A, Lock A, Misra G (1996) Psychological science in cultural context. American psychologist 51(5): 496.

48. Shotter J, Gergen KJ (1994) Social construction: Knowledge, self, others, and continuing the conversation. Annals of the International Communication Association 17(1): 3-33.

49. Hermans HJ, Kempen HJ (1993) The dialogical self: Meaning as movement. Academic Press, USA.

50.Gergen K (1991) The saturated self: Dilemmas of identity in contemporary life. Basic books.

51. Flory R, Miller D (2000) Generation X Religion. Gen X religion 231.

52. Krauss RM, Chiu CY (1998) Language and social behavior.

53. Bandura A (2001) Social cognitive theory: An agentic perspective. Annual review of psychology 52(1): 1-26.

This work is licensed under Creative

Commons Attribution 4.0 License

DOI: 10.19080/PBSIJ.2017.06.555680
54. Billig M (2009) Discursive psychology, rhetoric and the issue of agency. [Texteanglais original]. Semen. Revue de sémio-linguistique des textesetdiscours (27)

55. Potter J, Hepburn A (2007) Discursive psychology: Mind and reality in practice. In Language, discourse and social psychology. Palgrave Macmillan, UK.

56. Ajzen I (1991) The theory of planned behavior. Organizational behavior and human decision processes 50(2): 179-211.

57. Abrams D, Hogg MA (1990) The context of discourse: Let's not throw out the baby with the bathwater. Philosophical Psychology 2(3): 219225.

58. Wetherell M, Potter J (1992) Mapping the language of racism: Discourse and the legitimating of exploitation. Harvest-Wheatsheaf, Hertfordshire.

59. Willmott D (2016b) Stranger, Acquaintance \& Domestic: A Psychological Exploration of Jury Decision Making Within Three Differing Rape Trials. Paper presented at the $26^{\text {th }}$ Annual European Association of Psychology \& Law Conference, Toulouse: France.

60. Burr V (1998) Overview: Realism, relativism, social construction and discourse. Social construction, discourse and realism. 13-26.

61. Gergen KJ (2015) Culturally inclusive psychology from a constructionist standpoint. Journal for the Theory of Social Behaviour 45(1): 95-107.

62. Jefferson G (1989) List construction as a task and resource. In: Psathas G, (Eds.). Interactional Competence. New Jersey, USA.

63. Sherretts N, Willmott D (2016) Construct Validity and Dimensionality of the Measure of Criminal Social Identity using Data drawn from American, Pakistani, and Polish inmates. Journal of Criminal Psychology 6(3): 134-143.

\section{Your next submission with Juniper Publishers will reach you the below assets}

- Quality Editorial service

- Swift Peer Review

- Reprints availability

- E-prints Service

- Manuscript Podcast for convenient understanding

- Global attainment for your research

- Manuscript accessibility in different formats

( Pdf, E-pub, Full Text, Audio)

- Unceasing customer service

Track the below URL for one-step submission https://juniperpublishers.com/online-submission.php 